\title{
Organism Part
}

National Cancer Institute

\section{Source}

National Cancer Institute. Organism Part. NCI Thesaurus. Code C103199.

A portion of an organism. 